\title{
UPAYA MENINGKATKAN HASIL BELAJAR SISWA MELALUI MODEL PEMBELAJARAN KOOPERATIF TIPE STAD DI KELAS V MATA PELAJARAN PKN SD NEGERI 164522 TEBING TINGGI
}

\author{
Asmawati \\ Guru SD Negeri 164522 \\ Email: asmawatilubis@gmail.com
}

\begin{abstract}
Abstrak
Tujuan penelitian ini adalah untuk meningkatkan kemampuan siswa untuk hasil belajar siswa melalui model pembelajaran Kooperatif Tipe STAD pada Proses Belajar Mengajar (PBM) Pendidikan Kewarganegaraan di kelas V SD Negeri 164522 Tebing Tinggi. Penelitian Tindakan kelas ini dilakukan di SD Negeri 164522 Tahun Pelajaran 2014/2015 pada bulan Februari - April 2015. Objek yang diteliti adalah siswa kelas V SD Negeri 164522 Tebing Tinggi yang berjumlah 32 siswa. Penelitian ini terdiri atas tiga siklus yaitu, Siklus awal (45,71 \%), Siklus I (76,26 \%), Siklus II (92,18\%). Hasil penelitian menunjukan bahwa dengan penerapan metode Tipe Kooperatif STAD padamata pelajaran PKN dapat membantu siswa dalam memenuhi konsep pembelajaran dan mengasyikan untuk belajar bersama.
\end{abstract}

Kata Kunci : Hasil Belajar, Model Pembelajaran Kooperatif, Metode STAD

\section{PENDAHULUAN}

Kualitas pendidikan, sebagai salah satu pilar pengembangan sumberdaya manusia yang bermakna, sangat penting bagi pembangunan nasional. Bahkan dapat dikatakan masa depan bangsa bergantung pada keberadaan pendidikan yang berkualitas yang berlangsung di masa kini. Pendidikan yang berkualitas hanya akan muncul dari sekolah yang berkualitas.

Oleh sebab itu, upaya peningkatan kualitas sekolah merupakan titik sentral upaya menciptakan pendidikan yang berkualitas demi terciptanya tenaga kerja yang berkualitas pula. Dalam upaya peningkatan kualitas sekolah, tenaga kependidikan yang meliputi, tenaga pendidik, pengelola satuan pendidikan, penilik, pengawas, peneliti, teknis sumber belajar, sangat diharapkan berperan sebagaimana mestinya dan sebagai tenaga kependidikan yang berkualitas. Tenaga pendidik/guru yang berkualitas adalah tenaga pendidik/guru yang sanggup, dan terampil dalam melaksanakan tugasnya. Untuk memperjelas masalah yang akan dibahas, maka yang menjadi rumusan-rumusan dalam penelitian ini adalah:

a. Bagaimana cara meningkatkan kemampuan siswa untuk “ Menyebutkan contoh organisasi di lingkungan sekolah dan masyarakat" melalui model pembelajaran Kooperatif Tipe STAD pada Proses Belajar Mengajar (PBM) Pendidikan Kewarganegaraan di kelas V 
SD Negeri 164522 Tebing Tinggi ?

b. Bagaimana siswa menyikapi relevansi penerapan model pembelajaran Kooperatif Tipe STAD pada PBM Pendidikan Kewarganegaraan dalam meningkatkan hasil belajar ?

Adapun tujuan dari penelitian ini adalah sebagai berikut:

a. Mengetahui cara meningkatkan kemampuan siswa untuk Menyebutkan contoh organisasi di lingkungan sekolah dan masyarakat, pada PBM Pendidikan Kewarganegaraan di kelas V SD Negeri 164522 Tebing Tinggi melalui model pembelajaran Kooperatif Tipe STAD

b. Menganalisis bagaimana siswa menyikapi relevansi penerapan model pembelajaran Kooperatif Tipe STAD pada PBM Pendidikan Kewarganegaraan untuk meningkatkan ketuntasan dan hasil belajarnya.

Penelitian ini diharapkan dapat memberi manfaat sebagai berikut :

\section{Untuk Siswa}

a. Penelitian ini bermanfaat bagi siswa karena dapat meningkatkan kemampuan siswa kelas V SD Negeri 164522 Tebing Tinggi untuk Menyebutkan contoh organisasi di lingkungan sekolah dan masyarakat, pada PBM Pendidikan

Kewarganegaraan. b. Meningkatkan hasil belajar siswa.

c. Membantu siswa berfikir kritis, rasional dan kreatif dalam mengerjakan soal-soal Pendidikan Kewarganegaraan baik secara individual maupun kelompok.

d. Memberi peluang kepada siswa untuk lebih aktif mengembangkan potensi dirinya terutama dalam memberi pendapat-pendapat yang konstruktif positif untuk memecahkan masalah dalam soal-soal Pendidikan

Kewarganegaraan.

\section{Untuk Guru}

a. Penelitian ini bermanfaat bagi guru karena memberikan informasi dan konstribusi upaya meningkatkan kemampuan siswa tentang Menyebutkan contoh organisasi di lingkungan sekolah dan masyarakat, pada PBM Pendidikan Kewarganegaraan dengan model pembelajaran Kooperatif Tipe STAD.

b. Meningkatkan hasil belajar siswa.

c. Memberi konstribusi bagi guru tentang upaya penerapan model pembelajaran "Kooperatif Tipe STAD" yang menekankan pada siswa untuk menemukan konsep-konsep pengetahuan Pendidikan Kewarganegaraan (terutama yang berhubungan 
dengan konsep Menyebutkan contoh organisasi di lingkungan sekolah dan masyarakat) sehingga dapat diterapkannya dalam kehidupan.

d. Dapat meningkatkan profesionalisme dan kinerja guru serta menambah wawasannya tentang model pembelajaran "Kooperatif Tipe STAD" pada pembelajaran Pendidikan Kewarganegaraan.

\section{Untuk Sekolah}

a. Penelitian ini bermanfaat bagi sekolah karena dapat menjadi bahan masukan dan pertimbangan dalam meningkatkan hasil belajar siswa, khususnya dalam mata pelajaran Pendidikan Kewarganegaraan.

b. Penelitian ini bermanfaat bagi sekolah karena dapat memberi masukan atau sumbangan penelitian bagi peneliti lain yang melakukan Penelitian Tindakan Kelas (PTK).

c. Penelitian ini juga dapat bermanfaaat bagi sekolah terutama dalam meningkatkan kualitas pembelajaran dan kualitas akademik/ akreditasi.

d. Memotivasi guru lainnya di SD Negeri 164522 Tebing Tinggi untuk melakukan Penelitian Tindakan Kelas.

\section{TINJAUAN TEORI}

\section{Teori Hasil Belajar}

Hasil belajar secara teoritis dari berbagai sumber dapat disimpulkan adalah kemampuan siswa dalam menyerap materi yang disampaikan oleh Guru selama dalam proses belajar mengajar (PBM). Pembelajaran dikatakan berhasil apabila siswa mengalami peningkatan pengetahuan, kemampuan dan keterampilan sesuai dengan pengetahuan yang diperolehnya tersebut. Tingkat keberhasilan siswa tersebut dalam menyerap pengetahuan dinyatakan dalam bentuk Skor atau angka yang diberi nilai atau bobot tertentu. Apabila jumlah/persentase siswa dalam satu kelas mayoritas memperoleh angka atau bobot yang tinggi terhadap mata pelajaran tersebut maka proses pembelajaran tersebut dapat dikatakan berhasil. Namun akan terjadi sebaliknya, yaitu jika sebagian besar siswa di kelas tersebut tidak mampu memperoleh nilai/bobot yang tinggi terhadap mata pelajaran tersebut maka proses pembelajaran tidak berhasil.

\section{Pengukuran Hasil Belajar}

Hasil belajar atau keberhasilan dalam mencapai tujuan belajar perlu diukur agar Guru dan siswa mengetahui penguasaan dan pemahaman materi yang telah diajarkan sebelumnya. Penilaian hasil belajar menekankan pada informasi tentang seberapa jauh siswa telah mencapai kompetensi yang telah ditetapkan. Banyak alat 
ukur yang dapat digunakan untuk mengukur hasil belajar, diantaranya berupa test atau test hasil.

\section{Teori Belajar}

Menurut Sardiman ( 2001:93) bahwa : " Pada prinsipnya belajar adalah berbuat, berbuat untuk mengubah tingkah laku, jadi melakukan kegiatan. Proses Belajar tidak ada kalau tidak ada aktivitas. Itulah sebabnya aktivitas merupakan prinsip atau azas yang sangat penting di dalam interaksi belajar mengajar". Selanjutnya menurut pandangan ilmu jiwa modern Sardiman (2001:97) menerjemahkan bahwa :" Jiwa manusia itu sebagai sesuatu yang dinamis, memiliki potensi dan energi sendiri.

\section{Pendidikan Kewarganegaraan}

Pendidikan di Indonesia diharapkan dapat mempersiapkan peserta didik menjadi warga negara yang memiliki komitmen kuat dan konsisten untuk mempertahankan Negara Kesatuan Republik Indonesia. Hakikat negara kesatuan Republik Indonesia adalah negara kebangsaan modern.

Negara kebangsaan modern adalah negara yang pembentukannya didasarkan pada semangat kebangsaan --atau nasionalismeyaitu pada tekad suatu masyarakat untuk membangun masa depan bersama di bawah satu negara yang sama walaupun warga masyarakat tersebut berbeda-beda agama, ras, etnik, atau golongannya. [Risalah Sidang Badan Penyelidik Usaha- usaha Persiapan Kemerdekaan Indonesia (BPUPKI) dan Panitia Persiapan Kemerdekaan Indonesia (PPKI), Jakarta: Sekretariat Negara Republik Indonesia, 1998].

\section{Kerangka Berfikir}

a. Kemampuan berhubungan dengan Sikap dan perilaku yaitu suatu konsep psikologis yang bersifat labil, yaitu selalu berubah ditentukan oleh situasi dan kondisi. Guru sebagai mentor siswa perlu memahami konsep dasar ini, dan kemudian mengobservasi sikap dan perilaku siswa yang berbedabeda. Pemahaman terhadap sikap dan perilaku tiap siswa dapat mempermudah guru memberikan model pembelajaran Kooperatif Tipe STAD, karena model pembelajaran ini bersifat menstimulasi potensi dari tiap siswa saat berkelompok.

b. Setelah guru memahami perbedaan sikap dan perilaku siswanya, guru kemudian menjelaskan apa itu konsep sikap dan perilaku positif terhadap Ideologi Pancasila dan bagaimana cara mengembangkannya. Proses pengembangan ini dilakukan secara intensif, agar siswa mampu memaknai secara utuh konsep sikap dan perilaku positif terhadap ideologi tersebut. Saat pemahaman terhadap Ideologi Pancasila telah tumbuh berkembang 
secara baik, maka selanjutnya adalah pemberian tugas untuk mengeksplorasi lebih jauh lagi tentang pemahaman terhadap ideologi itu.

\section{Hipotesis Tindakan}

Dari kutipan uraian diatas peneliti membuat dugaan atau hipotesis tindakan dalam penelitian yang dilaksanakan di kelas V SD Negeri 164522 Tebing Tinggi, yaitu : Kemampuan siswa untuk menyebutkan contoh organisasi di lingkungan sekolah dan masyarakat melalui Model Pembelajaran Kooperatif Tipe STAD bagi siswa kelas V SD Negeri 164522 Tebing Tinggi akan meningkat setelah dilakukannya model pembelajaran tersebut.

\section{METODOLOGI PENELITIAN Jenis Penelitian}

Penelitian ini termasuk dalam kategori Penelitian Tindakan (action research), karena penelitian dilakukan untuk memecahkan masalah pembelajaran baik di kelas maupun di lapangan (luar kelas). Dinyatakan sebagai Penelitian Tindakan karena hasil penelitian ini dapat langsung ditindaklanjuti dalam bentuk tindakan kepada obyek penelitian yaitu siswa sekolah tempat penelitian ini dilaksanakan.

\section{Setting Penelitian}

Penelitian Tindakan kelas ini dilakukan di SD Negeri 164522 Tebing Tinggi Tahun Pelajaran 2014/2015 pada bulan Februari-
April 2014. Objek penelitian adalah siswa kelas V SD Negeri 164522 Tebing Tinggi yang berjumlah 32 siswa terdiri dari 13 siswa laki-laki dan 19 perempuan.

\section{Waktu Penelitian}

Penelitian ini menggunakan konsep aksi pada Action Research oleh Hopkin (1985), yang terdiri dari dua siklus dan masing-masing siklus menggunakan empat komponen tindakan yaitu, Perencanaan, Tindakan, Observasi dan Refleksi dalam suatu konsep yang saling terkait. Detail rancangan penelitian ini mengalami modifikasi sesuai dengan tujuan yang dicapai dijelaskan pada bagan dihalaman berikut ini. Rancangan penelitian adalah Penelitian Tindakan Kelas (PTK). Penelitian terdiri atas 2 siklus yang disebut dengan Siklus 1 dan Siklus 2. Siklus 1 dilaksanakan pada 20 Februari 2015 dan siklus 2 pada 27 Maret 2015.

Kegiatan pada setiap tahapan siklus adalah sebagai berikut :

\section{Siklus 1}

\section{Rencana tindakan}

Pada tahap ini peneliti melakukan beberapa aktivitas yaitu:

a. Membuat RPP tentang materi "Menyebutkan contoh organisasi di lingkungan sekolah dan masyarakat" pada mata pelajaran Pendidikan Kewarganegaraan

b. Menganalisis materi pelajaran tersebut diatas.

c. Dsb 


\section{Pelaksanaan Tindakan}

Pada tahap implementasi pelaksanaan tindakan ini Guru melakukan Model Pembelajaran Kooperatif Tipe STAD di ruangan kelas dengan menggunakan panduan perencanaan yang telah dibuat dengan menyusun kerangka dan jadwal rutin pelaksanaan model ini di dalam kelas sekolah.

\section{Observasi}

Guru/Peneliti sekaligus sebagai observator dibantu oleh beberapa alat perekam, pencatat, dan lembar observasi untuk menyelesaikan tujuan penelitian yaitu meningkatkan kemampuan siswa untuk " Menyebutkan contoh organisasi di lingkungan sekolah dan masyarakat" pada mata pelajaran Pendidikan Kewarganegaraan.

\section{Refleksi}

Data yang diperoleh pada lembar observasi, dianalisis. Kemudian dilakukan refleksi. Pelaksanaan refleksi merupakan hasil observasi/ pengamatan peneliti pada saat melakukan observasi penerapan Model Pembelajaran Kooperatif Tipe STAD yang bertujuan untuk mengevaluasi hasil tindakan yang telah dilakukan.

\section{Siklus ke 2}

Pada siklus kedua ini juga diadakan perencanaan seperti pada siklus satu yaitu tahap perencanaan, tindakan, observasi dan refleksi dalam suatu konsep yang saling terkait. Hanya saja pada siklus kedua ini ada perubahan yang menuju ke arah yang lebih baik jika dibandingkan dengan Siklus Satu.

\section{Instrumen Penelitian}

Instrumen yang digunakan dalam penelitian ini terdiri dari:
a. Rencana
Pelaksanaan
Pembelajaran (RPP)
b. Lembar Kegiatan Siswa
c. Lembar Observasi Kegiatan
Model
Pembelajaran
Kooperatif Tipe STAD

\section{Model Pengumpulan Data}

Data yang diperlukan dalam penelitian ini diperoleh melalui, observasi aktivitas siswa dan guru dalam model belajar tersebut, dan Tes Formatif.

\section{Teknik Analisis Data}

Untuk mengetahui keberhasilan suatu model dalam kegiatan model belajar perlu diadakan analisa data. Penelitian ini menggunakan Teknik Analisis Deskriptif Kualitatif, yaitu suatu model penelitian yang bersifat menggambarkan kenyataan atau fakta sesuai dengan data yang diperoleh dengan tujuan untuk mengetahui hasil model pembelajaran Kooperatif Tipe STAD yang dicapai siswa juga untuk memperoleh respon siswa terhadap kegiatan model belajar tersebut serta aktivitas siswa selama proses pembelajaran berlangsung.

\section{Untuk menilai ulangan}

Peneliti melakukan penjumlahan nilai yang diperoleh siswa, yang 
selanjutnya dibagi dengan jumlah siswa yang ada di kelas tersebut sehingga diperoleh rata-rata tes formatif dapat dirumuskan:

$\bar{X}=\frac{\sum X}{\sum N}$

Dengan :

$\bar{X}=$ Nilai rata-rata

$\Sigma X=$ Jumlah semua nilai siswa

$\Sigma \mathrm{N}=$ Jumlah siswa

\section{Untuk ketuntasan belajar}

Ada dua kategori

ketuntasan belajar yaitu secara perorangan dan secara klasikal.

Berdasarkan petunjuk pelaksanaan belajar mengajar kurikulum 1994 (Depdikbud, 1994), yaitu seorang siswa telah tuntas belajar bila telah mencapai skor $65 \%$ atau nilai 65 , dan kelas disebut tuntas belajar bila di kelas tersebut terdapat $85 \%$ yang telah mencapai daya serap lebih dari atau sama dengan $65 \%$. Untuk menghitung persentase ketuntasan belajar digunakan rumus sebagai berikut:

$P=\frac{\sum \text { Siswa.yang.tuntas.belajar }}{\sum \text { Siswa }} \times 100 \%$

\section{Untuk lembar observasi}

a. Lembar observasi pengelola model pembelajaran Kooperatif Tipe STAD . Untuk menghitung lembar observasi pengelolaan model pembelajaran

Kooperatif Tipe STAD digunakan rumus sebagai berikut :

$\mathrm{X}=\frac{P 1+P 2}{2}$

Dimana $\mathrm{P} 1=$ Pengamat 1 dan $\mathrm{P} 2$ = Pengamat 2

b. Lembar observasi aktifitas guru dan siswa

Untuk menghitung lembar observasi aktifitas guru dan siswa digunakan rumus sebagai berikut :

$$
\%=\frac{x}{\sum x} \times 100 \%
$$

dengan

$$
\mathrm{X} \frac{\text { Juma } h \text { hasil.pengama } \tan }{\text { Jumlah.pengama } \tan }=
$$$$
\frac{P 1+P 2}{2}
$$

Dimana $: \%=$ Persentase pengamatan

$$
\begin{array}{ll}
\mathrm{X} & =\text { Rata-rata } \\
\sum \mathrm{x} & =\text { Jumlah } \text { rata-rata } \\
\mathrm{P} 1 & =\text { Pengamat } 1 \\
\mathrm{P} 2 & =\text { Pengamat } 2
\end{array}
$$

\section{HASIL PENELITIAN DAN \\ PEMBAHASAN}

\section{Hasil Penelitian}

Hasil Kondisi Awal

Untuk mengetahui hasil penelitian, langkah pertama yang dilakukan peneliti adalah mengidentifikasi masalah melalui pengamatan proses belajar mengajar yakni rendahnya kemampuan siswa dalam " Menyebutkan contoh organisasi di lingkungan sekolah dan masyarakat" pada mata pelajaran Pendidikan Kewarganegaraan bagi 
siswa kelas V SD Negeri 164522

Tebing Tinggi, sehingga mempengaruhi nilai ketuntasan dan hasil belajar siswa di kelas $\mathrm{V}$ SD Negeri 164522 Tebing Tinggi yang berjumlah 32 siswa.

Proses pengamatan dilakukan dengan menggunakan daftar chek

\section{Hasil Observasi Kondisi Awal}

Aktivitas Siswa dalam Proses Pembelajaran

\begin{tabular}{|c|l|c|c|}
\hline NO. & \multicolumn{1}{|c|}{ Aspek yang Diamati } & $\begin{array}{c}\text { Jumlah } \\
\text { Siswa }\end{array}$ & Persen \\
\hline 1 & $\begin{array}{l}\text { Mendengarkan Penjelasan guru } \\
\text { dengan tekun }\end{array}$ & 28 & 87,5 \\
\hline 2 & $\begin{array}{l}\text { Ada usaha dan motivasi untuk } \\
\text { mempelajari bahan pelajaran atau } \\
\text { stimulus yang diberikan oleh guru }\end{array}$ & 15 & 46,9 \\
\hline 3 & $\begin{array}{l}\text { Dapat menjawab pertanyaan yang } \\
\text { diberikan oleh guru dengan benar pada } \\
\text { akhir pelajaran }\end{array}$ & 12 & 37,5 \\
\hline 4 & $\begin{array}{l}\text { Dapat bekerja sama dan } \\
\text { berhubungan dengan siswa lain }\end{array}$ & 16 & 50,0 \\
\hline 5 & $\begin{array}{l}\text { Mengajukan pendapat, bertanya atau } \\
\text { berkomentar kepada guru dan siswa }\end{array}$ & 6 & 18,75 \\
\hline 6 & $\begin{array}{l}\text { Aktif berdiskusi untuk memecahkan } \\
\text { masalah }\end{array}$ & 10 & 31,25 \\
\hline 7 & $\begin{array}{l}\text { Mengerjakan tugas yang diberikan } \\
\text { oleh guru dan Mampu membuat } \\
\text { simpulan sendiri tentang pembelajaran } \\
\text { yang diterimanya }\end{array}$ & 8 & 25,0 \\
\hline 8. & Hasil Belajar Tuntas & 22 & $\mathbf{6 8 , 7 5}$ \\
\hline & $\begin{array}{l}\mathbf{4 5 , 7 1} \\
\text { Rata-rata }\end{array}$ & & \\
\hline
\end{tabular}

\section{Hasil Siklus 1}

Dalam penelitian ini ada dua aspek yang ingin diukur yaitu Penilaian Proses Pembelajaran dan Hasil Pembelajaran. Tujuan penilaian adalah untuk mengetahui dan catatan lapangan. Untuk menilai hasil evaluasi peneliti melakukan ulangan-ulangan harian. Sedangkan observasi dilakukan dengan menggunakan daftar chek list dengan kriteria seperti yang tertra berikut ini

apakah siswa telah atau belum menguasai suatu kompetensi dasar

tertentu. Untuk Penilaian Proses Pembelajaran menggunakan teknik Tes. Sedangkan untuk menilai Hasil Pembelajaran menggunakan teknik Non Tes. 


\section{Tahap Perencanaan}

Siklus 1 dilaksanakan satu kali pertemuan yaitu 20 Februari 2015. Materi Pembelajaran yang menjadi bahan penelitian ini " Menyebutkan contoh organisasi di lingkungan sekolah dan masyarakat". Untuk mencapai effektivitas pembelajaran telah dibuat Rencana Pelaksanaan Pembelajaran yang disesuaikan dengan model pembelajaran yang akan diterapkan yaitu Model Pembelajaran Kooperatif Tipe STAD Pada tahap ini peneliti juga mempersiapkan perangkat pembelajaran yang terdiri dari RPP 1, soal tes dan alat-alat pengajaran yang mendukung.

\section{Tahap Pelaksanaan}

Siklus Pertama dilaksanakan sesuai dengan rencana, yaitu 20 Februari 2015. Pada Siklus Pertama ini jumlah Siswa yang hadir 32 orang. Jumlah ini merupakan jumlah keseluruhan siswa yang terdaftar di kelas V SD Negeri 164522 . Observer yang hadir pada pertemuan ini dua orang. Langkah pertama seperti yang ada dalam perencanaan pada Siklus Pertama.

\section{Tahap Pengamatan (Observasi)}

Selama proses pembelajaran berlangsung Guru dan Kolabolator/Observer melakukan penilaian proses dari pengamatan terhadap kinerja kelompok, maupun pada saat pleno dengan menggunakan lembar observasi yang telah disediakan.

Aspek Partisipasi /Keaktifan

Siswa yang diamati selama proses pembelajaran berlangsung meliputi :

Tabel 4.2. Hasil Observasi Siklus Pertama

Partisipasi Siswa dalam Proses Pembelajaran

\begin{tabular}{|c|l|c|c|}
\hline NO. & \multicolumn{1}{|c|}{ Aspek yang Diamati } & $\begin{array}{c}\text { Jumlah } \\
\text { Siswa }\end{array}$ & Persen \\
\hline 1 & $\begin{array}{l}\text { Mendengarkan Penjelasan guru } \\
\text { dengan tekun }\end{array}$ & 29 & 90,6 \\
\hline 2 & $\begin{array}{l}\text { Ada usaha dan motivasi untuk } \\
\text { mempelajari bahan pelajaran atau } \\
\text { stimulus yang diberikan oleh guru }\end{array}$ & 20 & 62,5 \\
\hline 3 & $\begin{array}{l}\text { Dapat menjawab pertanyaan yang } \\
\text { diberikan oleh guru dengan benar pada } \\
\text { akhir pelajaran }\end{array}$ & 22 & 68,75 \\
\hline 4 & $\begin{array}{l}\text { Dapat bekerja sama dan } \\
\text { berhubungan dengan siswa lain }\end{array}$ & 75,0 \\
\hline 5 & Mengajukan pendapat, bertanya atau & 18 & 56,25 \\
\hline
\end{tabular}




\begin{tabular}{|c|l|c|c|}
\hline & berkomentar kepada guru dan siswa & & \\
\hline 6 & $\begin{array}{l}\text { Aktif berdiskusi untuk memecahkan } \\
\text { masalah }\end{array}$ & 24 & 75,0 \\
\hline 7 & $\begin{array}{l}\text { Mengerjakan tugas yang diberikan } \\
\text { oleh guru dan Mampu membuat } \\
\text { simpulan sendiri tentang pembelajaran } \\
\text { yang diterimanya }\end{array}$ & 20 & 62,5 \\
\hline 8. & Hasil Belajar Tuntas & 28 & $\mathbf{8 7 , 5}$ \\
\hline & \multicolumn{1}{|c|}{ Rata-rata } & $\mathbf{7 2 , 2 6}$ \\
\hline
\end{tabular}

\section{Tahap Refleksi}

Berdasarkan hasil observasi yang dilakukan pada Siklus Pertama ini maka ada beberapa aspek yang perlu menjadi perhatian untuk ditingkatkan pada Siklus Kedua dalam Penelitian Tindakan Kelas ini.

\section{Hasil Penelitian Siklus 2}

Sama dengan pelaksanaan pada Siklus Pertama, maka pada Siklus Kedua ini ada dua aspek yang ingin diukur yaitu Penilaian Proses Pembelajaran dan Hasil Pembelajaran. Indikator yang digunakan juga sama dengan yang diterapkan pada Siklus Pertama yaitu ada 8 aspek yang diharapkan pada Siklus ke dua ini sudah mencapai 86 $\%$ ke atas bobot atau nilainya. Tinggi rendahnya tingkat partisipasi siswa dalam proses pembelajaran dapat diketahui dari nilai hasil pengamatan yang dilakukan.

\section{Tahap Perencanaan}

Siklus 2 dilaksanakan satu kali pertemuan yaitu 27 Maret 2015. Materi Pembelajaran yang menjadi bahan penelitian ini adalah Standar Kompetensi (SK) 5.

\section{Tahap Pelaksanaan}

Siklus kedua dilaksanakan sesuai dengan rencana yaitu 27 Maret 2015. Pada Siklus Kedua ini jumlah Siswa yang hadir 32 orang. Jumlah ini merupakan jumlah keseluruhan siswa yang terdaftar di kelas V. Observer yang hadir pada pertemuan ini dua orang.

\section{Tahap Pengamatan (Observasi)}

Selama proses pembelajaran berlangsung Guru dan Kolabolator/Observer melakukan penilaian proses dari pengamatan terhadap kinerja kelompok, maupun pada saat pleno dengan menggunakan lembar observasi yang telah disediakan.

Aspek Partisipasi /Keaktifan

Siswa yang diamati selama proses pembelajaran berlangsung meliputi : 


\section{Hasil Observasi Siklus Kedua \\ Partisipasi Siswa dalam Proses Pembelajaran}

\begin{tabular}{|c|c|c|c|}
\hline NO. & Aspek yang Diamati & $\begin{array}{l}\text { Jumlah } \\
\text { Siswa }\end{array}$ & Persen \\
\hline 1 & $\begin{array}{l}\text { Mendengarkan Penjelasan guru } \\
\text { dengan tekun }\end{array}$ & 31 & 96,87 \\
\hline 2 & $\begin{array}{l}\text { Ada usaha dan motivasi untuk } \\
\text { mempelajari bahan pelajaran atau } \\
\text { stimulus yang diberikan oleh guru }\end{array}$ & 28 & 87,5 \\
\hline 3 & $\begin{array}{l}\text { Dapat menjawab pertanyaan yang } \\
\text { diberikan oleh guru dengan benar pada } \\
\text { akhir pelajaran }\end{array}$ & 28 & 87,5 \\
\hline 4 & $\begin{array}{l}\text { Dapat bekerja sama dan } \\
\text { berhubungan dengan siswa lain }\end{array}$ & 30 & 93,75 \\
\hline 5 & $\begin{array}{l}\text { Mengajukan pendapat, bertanya atau } \\
\text { berkomentar kepada guru dan siswa }\end{array}$ & 29 & 90,6 \\
\hline 6 & $\begin{array}{l}\text { Aktif berdiskusi untuk memecahkan } \\
\text { masalah }\end{array}$ & 29 & 90,6 \\
\hline 7 & $\begin{array}{l}\text { Mengerjakan tugas yang diberikan } \\
\text { oleh guru dan Mampu membuat } \\
\text { simpulan sendiri tentang pembelajaran } \\
\text { yang diterimanya }\end{array}$ & 30 & 93,75 \\
\hline 8. & Hasil Belajar Tuntas & 31 & 96,87 \\
\hline & Rata-rata & & 92,18 \\
\hline
\end{tabular}

\section{Tahap Refleksi}

Analisis terhadap pengamatan, catatan Guru dan diskusi dengan observer menunjukkan bahwa pada siklus ke dua telah terjadi peningkatan kemampuan siswa secara berkelompok dalam aktivitas siswa dan hasil belajarnya. Peningkatan kemampuan ini tercermin dari nilai yang diperoleh oleh kelompok siswa yang menunjukkan nilai telah berada di atas standar Kriteria Ketuntasan Minimal (KKM) yaitu 70.
Proses Menganalisa Data

Keaktifan Siswa sebelum Penerapan Model Pembelajaran Kooperatif Tipe STAD

Sebagaimana diuraikan pada latar belakang penelitian ini bahwa aktivitas siswa atau partisipasi siswa dalam proses pembelajaran sangat rendah sehingga pembelajaran dirasakan kurang bermakna dan kurang membangun potensi atau pengetahuan yang telah dimilikinya. Akibatnya, hasil belajar siswa untuk "Menyebutkan contoh organisasi di lingkungan sekolah dan masyarakat" pada mata pelajaran Pendidikan 
Kewarganegaraan bagi siswa kelas V SD Negeri 164522 Tebing Tinggi Tahun Pembelajaran 2014/2015 menjadi rendah.

Partisipasi Siswa setelah Penerapan Model Pembelajaran Kooperatif Tipe STAD

Penerapan model pembelajaran Kooperatif Tipe STAD merupakan salah satu solusi dalam mengatasi rendahnya tingkat partisipasi siswa sebagaimana diuraikan di atas. Tindakan ini diterapkan selama dua siklus terhadap siswa kelas V SD Negeri 164522 Tebing Tinggi, dan ternyata hasil penelitian kemampuan siswa tentang "Menyebutkan contoh organisasi di lingkungan sekolah dan masyarakat" pada mata pelajaran Pendidikan Kewarganegaraan bagi siswa kelas V SD Negeri 164522 Tebing Tinggi Tahun Pembelajaran 2014/2015 memperlihatkan peningkatan yang cukup signifikan (berarti).

\section{SIMPULAN DAN SARAN}

\section{Simpulan}

a. Dari aspek Partisipasi siswa dalam pembelajaran pada Siklus ke dua semua aspek mengalami peningkatan yang cukup signifikan. Semua siswa sudah terlibat dan aktif berdiskusi untuk memecahkan masalah sudah mencapai 29 siswa (90,6 \%). Begitu juga kemampuan siswa untuk Mengajukan pendapat, bertanya atau berkomentar kepada guru dan siswa dari 18 orang meningkat menjadi 29 orang (90,6 \%). Kemampuan dan kemauan siswa untuk Mengerjakan tugas yang diberikan oleh guru dan membuat simpulan sendiri tentang pembelajaran yang diterimanya juga meningkat menjadi $93,75 \%$ atau 30 orang siswa.

b. Pada Siklus Kedua, siswa yang dapat belajar tuntas sudah mencapai 31 orang $(96,87 \%)$ .Secara ringkas dapat disimpulkan bahwa hasil Siklus Kedua dari aspek Partisipasi /Keaktifan Siswa dalam proses pembelajaran sudah tercapai secara optimal, sebab rata-rata persentase yang dicapai sudah 92,18\% .

c. Pada Siklus ke dua, persentase ketuntasan belajar siswa juga meningkat yaitu dari 32 siswa, pada Siklus pertama hanya 28 Siswa yang termasuk dalam kategori sudah tuntas belajar menjadi 31 siswa yang termasuk dalam kategori Tuntas Belajar. Sehingga pada Siklus Kedua ini persentase kelulusan siswa sudah mencapai $92,18 \%$, artinya model Kooperatif Tipe STAD sudah dapat meningkatkan kemampuan siswa " Menyebutkan contoh organisasi di lingkungan sekolah dan masyarakat" pada mata pelajaran Pendidikan Kewarganegaraan bagi siswa kelas V SD Negeri 164522 Tebing Tinggi Tahun Pelajaran 2014/2015.

\section{Saran}


Berdasarkan hasil Penelitian Tindakan kelas yang peneliti laksanakan dapat dikemukakan saransaran yang bermanfaat pagi peneliti selanjutnya, Guru dan Sekolah sebagai berikut :

a. Proses pembelajaran Pendidikan Kewarganegaraan hendaknya dapat dilakukan secara bervariasi, tidak monoton dan berorientasi kepada kebutuhan siswa sehingga hasil pembelajaran dapat mendapatkan hasil yang maksimal.

b. Keterlibatan siswa dalam proses pembelajaran hendaknya dapat lebih ditingkatkan sehingga siswa dapat lebih memiliki kemampuan dalam mengemukakan pendapat dan berdiskusi, sehingga proses pembelajaran dapat berlangsung lebih menyenangkan.

c. Bagi Guru yang akan melaksanakan Penelitian Tindakan Kelas hendaknya lebih memperhatikan aspek validitas instrumen penelitian agar hasil penelitiannya dapat lebih akurat dan berkualitas.

d. Pihak sekolah hendaknya selalu mendukung dan memfasilitasi para Guru yang akan melakukan PTK karena hasilnya dapat meningkatkan kualitas pembelajaran di sekolah tersebut.

\section{DAFTAR RUJUKAN}

Abdullah, A,E. 1989. Pokok-pokok Layanan Bimbingan Belajar. Ujung Pandang; Fakultas Ilmu Pendidikan IKIP Ujung Pandang.

Abdurrahman, H. 1990. Pengelolaan pengajaran. Bandung: Tarsito.

Ahmadi, Abu. 1998. Didaktik Metodik. Cet.II; Semarang: CV. Toha Putra.

Ali, M. 1993. Guru dan Proses Belajar Mengajar. Bandung: Sinar Baru Algesindo.

Anonim, 1998. Garis-garis Besar Haluan Negara. Jakarta: Departemen Pendidikan Nasional.

Arikunto, S. 1993. Prosedur Penelitian dan Penilaian Hasil Belajar. Jakarta: Bina Aksara.

1993. Dasar-dasar Evaluasi dan pendekatan Praktek. Jakarta: Bina Aksara.

Bahri, D.S. 1994. Hasil Belajar dan Kompetensi Guru. Surabaya: Usaha nasional.

Boediono. 1998. Pembinaan Profesi Guru dan Psikologi Pembinaan Personalia. Jakarta: Departemen Pendidikan dan Kebudayaan.

Edward., J.D. 1995. Statistik Matematika Modern. Jakarta: PT. Gramedia Pustaka Utama.

Gie. 1995. Cara Belajar yang Efisien. Yogyakarta: Liberti.

Hardjana. 1994. Kiat Sukses di Perguruan Tinggi. Yogyakarta: Kanisius. 
Hudoyo, H. 1984. Pengembangan

Kurikulum. Surabaya: Usaha

Nasional.

Loekmono. 1994. Belajar Bagaimana

Belajar. Jakarta: BPK Gunung Mulia.

Mappa, S, 1970. Psikologi Pendidikan. Ujung pandang: Fakultas Ilmu pendidikan IKIP Ujung pandang.

Mardanu. 1997. Peranan Orang Tua dalam Upaya meningkatkan Mutu Pendidikan anak. Jakarta: Cakrawala Pendidikan.

Mathis dan Jackson. 2002. Manajemen Sumber Daya Manusia. Jakarta: Salemba Empat.

Muhtar. 1992. Pedoman Bimbingan Guru dalam Proses Belajar Mengajar. Jakarta: PGK \& PTK Dep.Dikbud. 